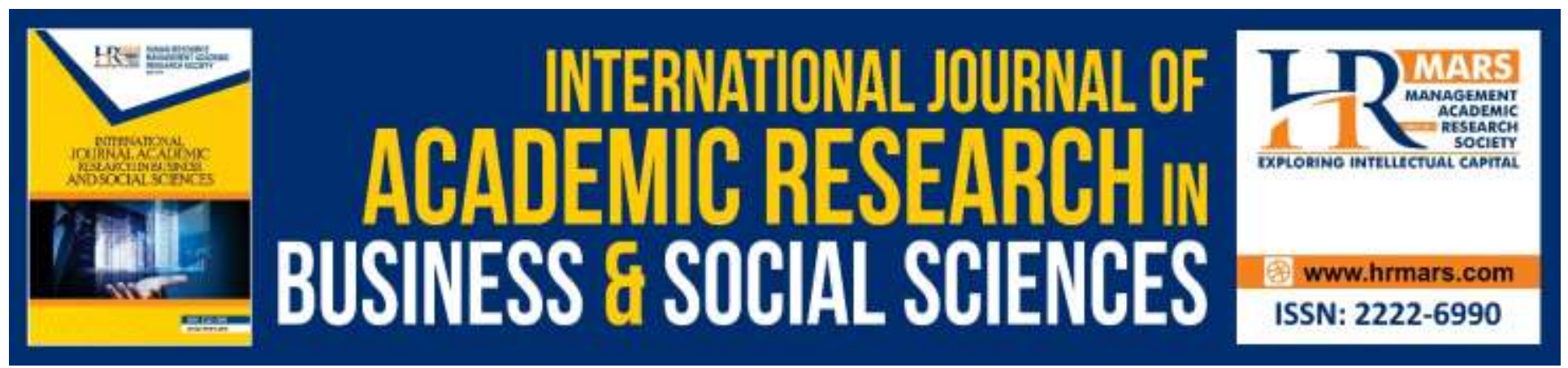

\title{
Impact of Sports Sponsorship on Share Prices of Sponsoring Firm: Evidence from Pakistan Supper League (PSL)
}

Hafiz Muhammad Naveed, Yao Hongxing, Muhammad Haris, Khalid Hussain, Saqib Altaf, Hafiz Muhammad Naveed, Yao Hongxing, Muhammad Haris, Saqib Altaf, Muhammad Khalid

To Link this Article: http://dx.doi.org/10.6007/IJARBSS/v10-i6/7286

DOI:10.6007/IJARBSS/v10-i6/7286

Received: 02 April 2020, Revised: 12 May 2020, Accepted: 30 May 2020

Published Online: 09 June 2020

In-Text Citation: (Naveed et al., 2020)

To Cite this Article: Naveed, H. M., Hongxing, Y., Haris, M., Hussain, K., Altaf, S., Naveed, H. M., Hongxing, Y., Haris, M., Altaf, S., \& Khalid, M. (2020). Impact of Sports Sponsorship on Share Prices of Sponsoring Firm: Evidence from Pakistan Supper League (PSL). International Journal of Academic Research in Business and Social Sciences, 10(6), 268-283.

Copyright: (C) 2020 The Author(s)

Published by Human Resource Management Academic Research Society (www.hrmars.com)

This article is published under the Creative Commons Attribution (CC BY 4.0) license. Anyone may reproduce, distribute, translate and create derivative works of this article (for both commercial and non-commercial purposes), subject to full attribution to the original publication and authors. The full terms of this license may be seen

at: http://creativecommons.org/licences/by/4.0/legalcode

Vol. 10, No. 6, 2020, Pg. $268-283$

http://hrmars.com/index.php/pages/detail/IJARBSS

JOURNAL HOMEPAGE

Full Terms \& Conditions of access and use can be found at http://hrmars.com/index.php/pages/detail/publication-ethics 


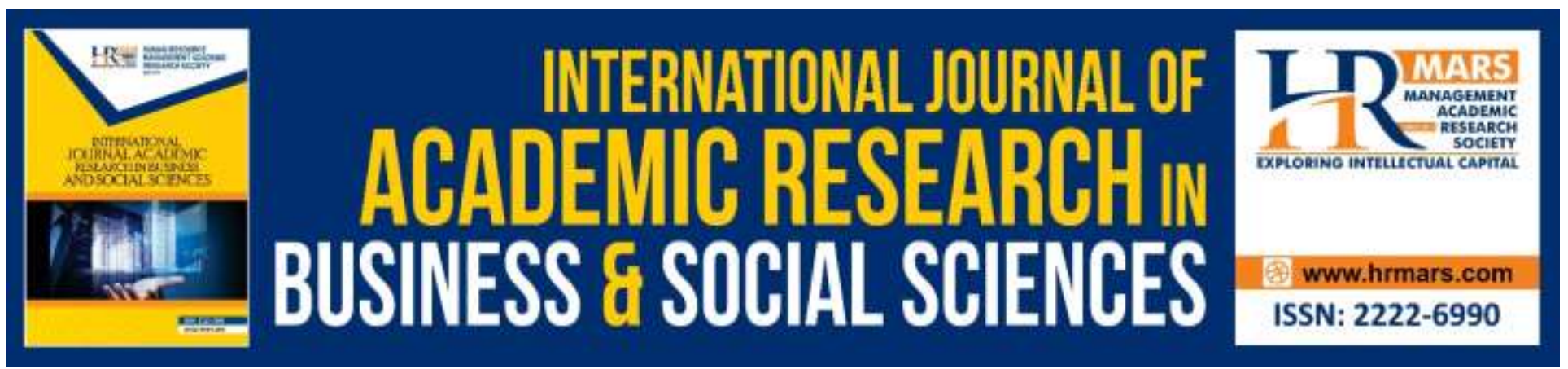

\title{
Impact of Sports Sponsorship on Share Prices of Sponsoring Firm: Evidence from Pakistan Supper League (PSL)
}

Hafiz Muhammad Naveed, Yao Hongxing, Muhammad Haris, Khalid Hussain, SaqibAltaf, Hafiz Muhammad Naveed, Yao Hongxing, Muhammad Haris

School of Finance and Economics, Jiangsu University, Zhenjiang 212013, China

Email: Hafiznaveed778@gmail.com, hxyao@ujs.edu.cn, Haris-malik1@outlook.com

\section{Saqib Altaf}

School of Management, Jiangsu University, Zhenjiang 212013, China

Email: saqibaltaftareen@outlook.com

\section{Muhammad Khalid}

Quality Control Laboratory Food Department Bahawalpur 63100, Government of Punjab, Pakistan Email: Khalidskha@gmail.com

\begin{abstract}
This empiricalstudy examinesthe effect of sports sponsorship announcements (SSA) on the share price (SP) of the sponsoring firm(Habib Bank Limited) by examiningnormal/actual returns, abnormal returns and expected returns.For this purpose, secondary data was collected ten days before \& afterSP of HBL from SSA and utilized window-based methodology to accomplish the actual outcomes. The results ofthis window-based study showsthat SSA has a significant impact onSPof HBLand also positively impact onstock returnsof HBL. Besides, if comparatively visualize the consequences then market return (MR) ofHBL isslightly higher than the Karachi stockexchange KSE100 index return. This study suggests thatsponsoring the sports events enhances the market capitalization and stock returns of sponsoring firms.
\end{abstract}

Keywords: Share Prices, Sports Sponsorship Announcement, Karachi Stock Exchange, Habib Bank Limited. 


\section{Introduction}

Marketing transformation through major sponsorship events brings significant changes in different aspects of traditional advertising techniques i.e., media choice, placement, contents and pattern of spending are different in various sponsoring organizations (Cornwell, Pruitt, \& Clark, 2005).Marketing and Advertising techniques are more experienced to makesa firm image during the last two decades. Recent Scholars have gone far-off from conventional advertising practice at the hand of technological development \& media destruction. These changes lead to nontraditional promotional techniques as sports sponsorship marketing(Cornwell, Pruitt, \& Clark, 2004).Firms are sacrifice financial investment to keep safe and sound their position and privilege to develop the commercial potential of association(Meenaghan \& Flood, 1983).In thepresent, sports sponsorship has become a popular means of advertisement, promotion and brand development of their products and services. Companies spend million dollars because football and cricket audience are targeted through TV and other media source resulting firms expect that sports sponsorship is the primary mean to elaborate their vision. It is also a source to promote the sale, advertising public relations and personal selling as its efforts indirectly to persuade consumers (Meenaghan \& Shipley, 1999). Another Important purpose of sponsorship is to gain a sustainable competitive advantage of sponsorship in the market. In communication mix sponsorship has increased attention to effective measures; however, to measure sponsorship effectiveness, there is no universally accepted approach available (Garland, Charbonneau, \& Macpherson, 2008).

Sports Sponsorship directly influences individuals by adequate marketing information about their product as well as Sponsorship leads to an impact on the Brand Value of a Company. Alain Ferrand (1999) has defined the Sports Sponsorship through advertisement is added value creation for sponsoring organizations. Sponsorship is considered valuableas a commutative advantage and influences directly targeted consumers.Furthermore, profits generatewhenever Sales, Marketing and Advertising departments are working effectively and efficiently which ultimately consequences gather hight profits. Noteworthy, football sponsorship for sponsoring has turned into a well-known path for organizations to advance their image from the market perspective. The TV group consideration of some critical football occasions attained hundred a large number of individuals. Thus, organizations think they can support their equity rapidly through football sports sponsoring. The aimof the presentresearch study has diagnosed whether sponsoring a sport-event is a positive impact on the share price of the sponsoring firm or not.

\section{Research Objective}

- Forecasting pre \& post performances of the share prices of sponsoring firm by using window based methodology.

- Diagnose the impact of spots sponsorship on share prices of sponsoring firm from the day of sponsor announcement.

The leaving part of this studycontains on the following sections: in section 2, a comprehensive review of previous relevant literature. In chapter 3, describeunderutilizing research methodology techniques. In part 4, consists of results and discussion and section 5, is on the conclusion of the study. 
INTERNATIONAL JOURNAL OF ACADEMIC RESEARCH IN BUSINESS AND SOCIAL SCIENCES

Vol. 10, No. 6, June, 2020, E-ISSN: 2222-6990 @ 2020 HRMARS

\section{Literature Review and Research Hypothesis Sports Sponsorship}

Provision of assistance either financial or inkind to as activity by a commercial organization to achievebusiness objectives"(Meenaghan, 1993). In specific sports, sports sponsorship plays a vital role in linking, aspire and passion of the target audience(Arun, 2004). Fromthe last decade,the number of companies is going to sponsor different events of sportsbecause sponsorship holds a unique position in marketing-mix. Sports sponsorship is useful in providing valuable networking, increasing sales, advertisement, hospitality opportunities and building brand awareness. Besides, Clark, Cornwell, and Pruitt (2009), have defined the sponsorship as "cash and kind fee paid to a property (typically a sport, entertainment, non-profit event or organization) in return for access to the exploitable commercial potential associated with that property." In general, sponsorship can be expected to influence future cash flows for a number of reasons as chronicled by (Mishra, Bobinski Jr, \& Bhabra, 1997). On the positive side, sponsorship may improve esprit cooperation among employees, build image and awareness with consumers, facilitate channel member acceptance and promote goodwill. On the negative side, the potential of agency problems and the challenges of inter-organizational coordination (Mishra et al., 1997). Moreover, the current research study has taken two appropriate approaches to sports sponsorships with detail in the next section.

\section{Share Prices}

Several previous empirical studies have examined the impact of major SSA on the stock prices of corporate sponsors (Clark, Cornwell, \& Pruitt, 2002; Comwell, Pruitt, \& Van Ness, 2001; T. B. Cornwell et al., 2005; Miyazaki \& Morgan, 2001; Pruitt, Cornwell, \& Clark, 2004).The share pricesare the market value of the share of a company at a particular time in the specified market in which its shares are traded, although the share price is considered in different perspectives. The significant ambition of an event investigates the positive or negative impressions taken by the market for a specific firm's share to measure the effect on the share prices. Similarly, to identify the returns of an event announcement sponsorship for the prescribed period as well as abnormal share price returns are calculated. Primarily, it is imperative to pinpoint the usage of share price return, either negative or positive of the respective share of an organization derived. Kim, Shamsuddin, and Lim (2011), have explored that abnormal returns of shares offer an unbiased estimation of the sponsorship event or investment. The difference between expected return which is based on the traded general market and the actual returns of share prices earned by the under observation recognized abnormal return for the event or investment (Kim \& Morris, 2003). With a slight difference, it described that abnormal return is the difference between the return of share during the period of the announcement and normal expected return in assumption with that announcement had not been taken.

H1:There is a positive and significant relationship between sports sponsorship and share prices of sponsoring firms.

\section{Research Methodology}

This section leads to under description research methodology for exposed the effect of PS sponsorship announcement on Share Price of the HBL. In addition, the entire research study used a time-scale methodology for decomposition pre-post deviations in SPP of sports sponsoring firms. Numerous scholars have functionalized similar research methodology in fields including marketing, 
INTERNATIONAL JOURNAL OF ACADEMIC RESEARCH IN BUSINESS AND SOCIAL SCIENCES

Vol. 10, No. 6, June, 2020, E-ISSN: 2222-6990 @ 2020 HRMARS

sale, profitability which usuallycalled "market model" utilized to estimate the stock market returns of sponsor and to measure the effects of an event for sponsor(Clark et al., 2009).

\section{Research Population\& Sample Size}

$\mathrm{HBL}$ and five other organizations sponsoredPSLin 2015 thatwere nominated population forthe presentresearch study. But PSL was officially sponsored by HBL;thus, HBL elected forestimation the impact of sponsorship on itsshare price. Moreover, virtually five organizations sponsor different teams of PSLbut HBL sponsoredas a whole event while HBL of Pakistan has become a sample of current research study to bring accurate forecasting of sponsoring effect.

\section{Data Collection Techniques}

In this sort of research study, a secondary source of data has utilized based on historical share prices. Secondary based data has collected the historical share price of HBLsince the date of sponsorship announcement via https://markets.ft.com/data/equities/tearsheet/historical?s=HBL:KAR, and event-window will create before and after the event.

\section{Data Analysis Techniques}

Several research studiesaccomplished on event-window based research technique thatarean appropriate way to evaluate the effects of the events (announcement of sponsorship) on the stock price market model. Only the market model is super fit to assess the impact of an event base study; therefore, event-window based methodology hasapplied for test sponsoring effect(Pynnonen, 2005). This empirical research study has also gained an event-window based research technique by executing MS-Excel for analysispre-post deviation.

\section{Abnormal Returns}

Ross, Westerfield, and Jaffe (2012), have pinpointed as the difference between the actual and expected return is called an abnormal return. Essentially it is imperative to determine the usage of share price return, either negative or positive of the respective share of an organization calculated. The difference between expected return which is based on the traded general market and the actual returns of share prices earned by the under observation is called abnormal return for the event or investment (Kim \& Morris, 2003). In addition, (Kim \& Morris, 2003; Miyazaki \& Morgan, 2001; Pruitt et al., 2004), have found a good indicator to identify the impact of sports sponsorship on the share price of the sponsor and changes of the share price of sponsoring firm in the respective stock market.

$$
\text { (1) } A R_{i t}=R_{i t}-\alpha_{i}-\beta_{i} R_{m t}
$$

The ARit is abnormal return, Rit is the actual return at share price i at time tof sponsoring firms, $\alpha \mathrm{i}$ is the Intercept, $\beta \mathrm{i}$ is the slope and $\mathrm{Rmt}$ is the actual return of the market at time $t$. These parameters are obtained by estimating the interval of the time trading of the share prices which is 21 days, starting from 10 trading days before the event (Sponsorship Announcement) and ten trading days after the event and one is being on the event date.

\section{Actual Return}

The actual return is the return of an organization in which a firmhas gain profit and loss during a specified time of period. According 
INTERNATIONAL JOURNAL OF ACADEMIC RESEARCH IN BUSINESS AND SOCIAL SCIENCES Vol. 10, No. 6, June, 2020, E-ISSN: 2222-6990 @ 2020 HRMARS

(http://www.investopedia.com/terms/a/actualreturn.asp\#ixzz4hKmFg5Fj), "An actual return is the actual gain or loss of an investor. It can be expressed bythe following formula: expected return (exante) plus the effect of firm-specific and economy-wide news". Furthermore,(Stock), has also defined actual return as the nominal return made during a given period on investment. (Kim 2010), has determinedthat actual return is the real loss or gain of an investor for the investment. (www.finance-acadmy.thefreedictionary.com)\&(Hassan, Imran, Amjad, and Hussain (2014)), have describedthe actual return following way "The return or yield on an investment or portfolio" which an essential aspect of an investment's risk analysis. Actual return designed with the following equation;

$$
\text { (2) } A R_{i t}=R_{i t}-E\left(R_{i t} \mid X_{t}\right)
$$

\section{Expected Return}

An expected return is that return which an individual firm or organization anticipated for the next time of period. The actual returnoften seems withdeviation into time span,mainly it was an expectation about a specified share price return. Moreover, the actual return might bethe same, lower or higher than the expected return. However, the expectation of an individual firm's return is usually the average return of security based on previous returns.As discussed, the market model will be utilized to analyze the impact of the sponsorship announcement on the share price of HBL.

\section{Estimation Window}

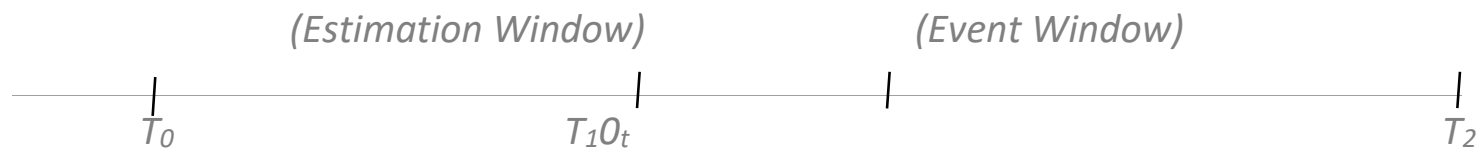

Figure1

Now we have the estimated normal return for the sponsor's stock and able to find abnormal returns as well, and these results will be key elements to investigate the impact of the announcement.

\section{Results and Discussion}

\section{Before Event Window Forecasting}

Before the event-window are summarized in Table 1, Figure 1 and 2. Here we are taking a comparative view between share prices of HBL and KSE-100 Index. The share prices of HBL start from 212.40 and after a specific time of period wasclosedon 201.20. In asimilar period as for HBL, the closing rate of KSE-100 Index starts from 33908.44 and was closed on 32392.92. The trend of HBL and KSE-100 Index have negative before the event. In addition, the overall share price of HBL has decreased by $5.57 \%$ and KSE-100 Index fell by $4.68 \%$. Thus, it concludes that HBL closing share price has inefficient rather than KSE-100 Index. 
INTERNATIONAL JOURNAL OF ACADEMIC RESEARCH IN BUSINESS AND SOCIAL SCIENCES Vol. 10, No. 6, June, 2020, E-ISSN: 2222-6990 @ 2020 HRMARS

Table 1. Comparison between share prices of HBL\& KSE-100 Index

\begin{tabular}{ccc}
\hline No. Days & Share prices of HBL & KSE-100 Index \\
\hline 1 & 212.4 & 33908.44 \\
2 & 212.1 & 33857.45 \\
3 & 213.1 & 33732.91 \\
4 & 212.5 & 33571.59 \\
5 & 207.5 & 33199.86 \\
6 & 206.7 & 33079.37 \\
7 & 207.9 & 32960.27 \\
8 & 204.9 & 32255.02 \\
9 & 199.2 & 31709.36 \\
10 & 201.2 & 32392.92 \\
\hline Total $\Delta$ & $-5.57 \%$ & $-4.68 \%$
\end{tabular}

Note: overall percentage \% Increase or Decrease of Share Prices

Now we demonstrate the share prices of HBL and KSE-100 through line-trend before sponsoring announcement. Figure 1 describes the trend line of Share Prices of HBL before the event of sponsorship held on 03 December, 2015. The trend line of HBL presents that the share price of HBL is falling before the event sponsorship. Its share prices start from Rs. 212.40 and continue to fall in share prices is shown in the below figure. Moreover, in figure-2, we can see that the closing of the KSE-100 Index is also falling as the HBL presented line trend. The absolute outcome indicates that the trend of $\mathrm{HBL}$ and $\mathrm{KSE}-100$ Index both are suffering toward the negative side before the event sponsoring announcement.

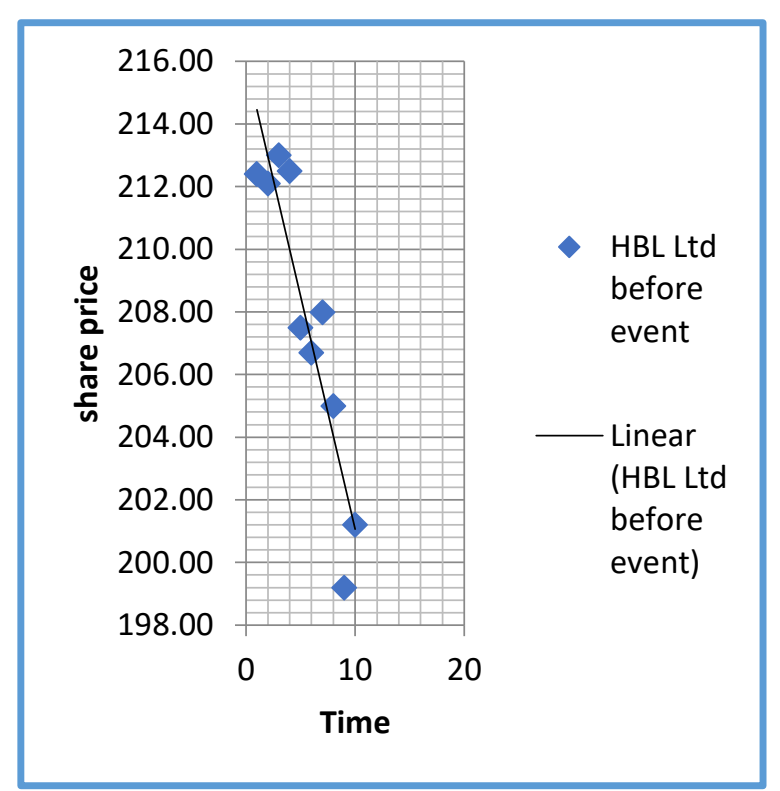

KSE-100 Index before the event window

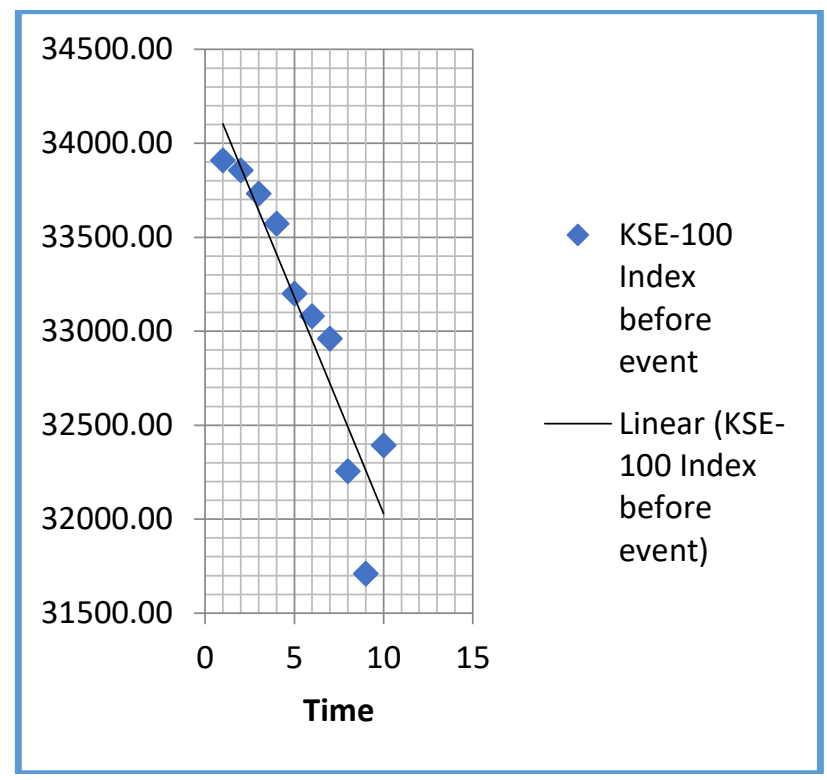

Figure 1.Share Pricesof HBL
Figure
2. 
INTERNATIONAL JOURNAL OF ACADEMIC RESEARCH IN BUSINESS AND SOCIAL SCIENCES Vol. 10, No. 6, June, 2020, E-ISSN: 2222-6990 @ 2020 HRMARS

\section{After Event Window forecasting}

After event forecasting of share prices of HBL and KSE-100 Index are concluded in Table 2, Figures 3 and 4. In table-2 a comparative view of the share price of Habib Bank Limited (HBL) and the Karachi Stock Exchange 100 Index (KSE-100) after the event (Sponsorship Agreement) among Habib Bank Limited and Pakistan Super League assigned 03 December, 2015. The share price of HBL was started from 209.00 and closed on 220.95 the first day after the event-window. Share prices of HBL did not decrease from the primary point of 209.00 after the event announcement. The share price of HBL goes up after sponsorship events while it indicates that the event has a positive impact on the share prices of HBL. On the other hand, at the same time of period, the KSE-100 Index started from 32707.91 and closed on 33109.54 collectively. Thus, the trend of HBL and KSE-100 Index have positive after the event announcement. Furthermore, the HBL share prices are overall increased by $5.41 \%$ and KSE-100 Index increased by $1.21 \%$. Consequently, after sponsoring the announcement the KSE-100 Index is inefficient rather than HBL share prices.

Table2.Comparison between Share Prices of HBL and KSE-100 Index after event window

\begin{tabular}{ccc}
\hline Sr. No & Share price of HBL after event & KSE-100 Index after event \\
\hline 1 & 209.00 & 32707.91 \\
2 & 210.00 & 32853.54 \\
3 & 211.00 & 32791.71 \\
4 & 214.95 & 33020.26 \\
5 & 214.01 & 33211.92 \\
6 & 215.25 & 33048.51 \\
7 & 216.88 & 32757.82 \\
8 & 215.99 & 32467.04 \\
9 & 215.25 & 32714.60 \\
10 & 220.95 & 33109.54 \\
\hline Total $\Delta$ & $\mathbf{5 . 4 1 \%}$ & $\mathbf{1 . 2 1 \%}$ \\
\hline
\end{tabular}

Note: Percentage\% Increase or Decrease of Share Price

Figure 3 estimates the share prices trend of $\mathrm{HBL}$ after the event sponsorship announcement. Visualizing, in the respective figure, the share prices of HBL have continuously increased after the sponsorship of the PSL event which shows that the sponsorship does positively affect the share price of HBL. Furthermore, figure 4collectively to measures the post-event window of and KSE-100 Index. The post-event window of the KSE-100 Index indicates a high fluctuated closing price whether the trend line shows the slightly +tive trend overall. The growth of the KSE-100 Index closing is less than the growth rate of $\mathrm{HBL}$ closing share prices. 
INTERNATIONAL JOURNAL OF ACADEMIC RESEARCH IN BUSINESS AND SOCIAL SCIENCES

Vol. 10, No. 6, June, 2020, E-ISSN: 2222-6990 @ 2020 HRMARS

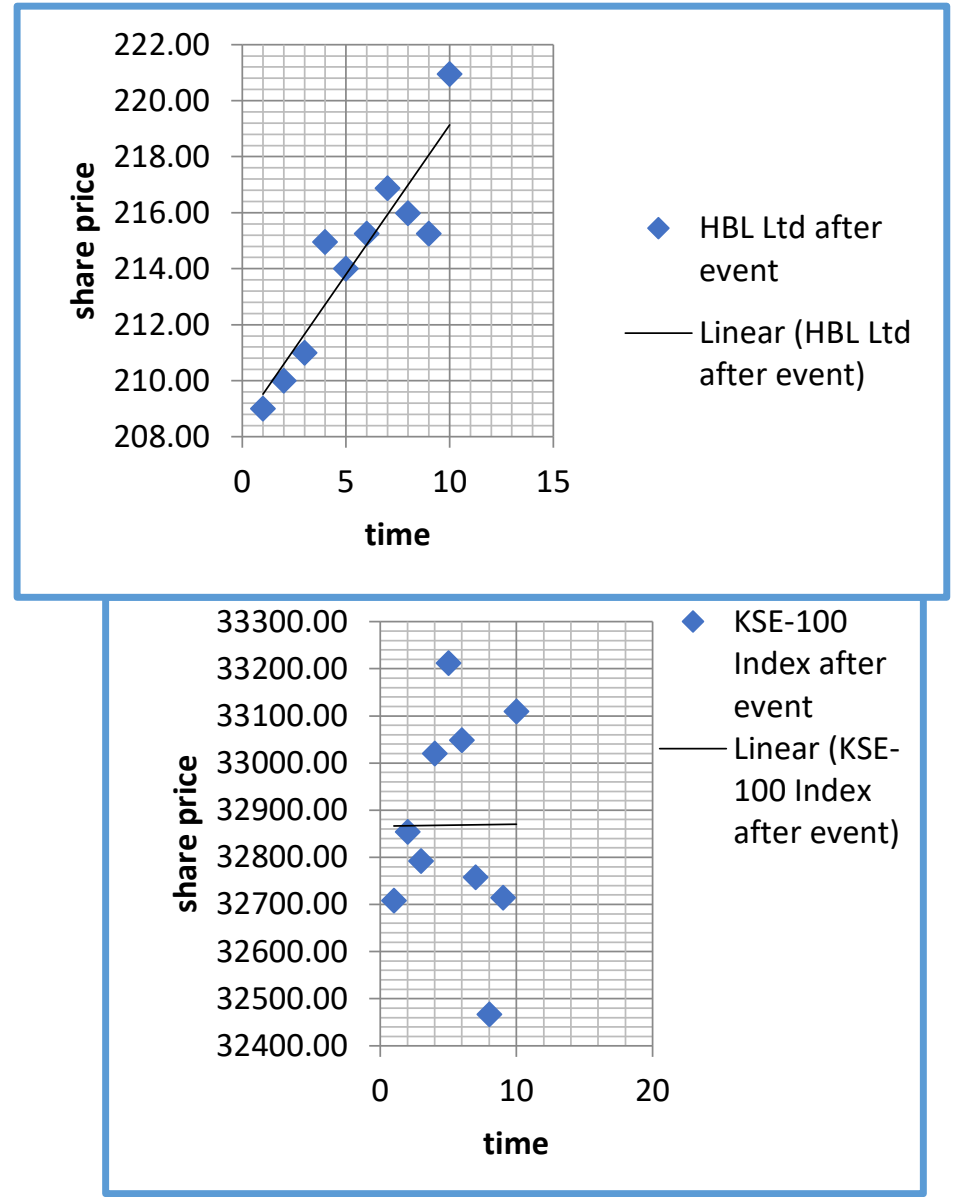

Figure 3.Share Prices of HBL after event
Figure 4.KSE-100 Index after event

\section{Comparison of share prices of HBL Before and After Event Window}

In table-3 a comparative view exposed to share prices of HBL before and after the event which organized on03 December, 2015. If we deliberate sum-up to before the event-window, the share prices of HBL continuously go down which starts from 212.40 and closes on 201.20. On the other hand, share prices of HBL consistently go up after the event windows which start from 209.00 and it closes on 220.95 that you see in column 2. Consequently, before the event window < after the event window. 
INTERNATIONAL JOURNAL OF ACADEMIC RESEARCH IN BUSINESS AND SOCIAL SCIENCES Vol. 10, No. 6, June, 2020, E-ISSN: 2222-6990 @ 2020 HRMARS

Table 3.Before and after comparative event view of Share Price of HBL

\begin{tabular}{ccc}
\hline Sr. No & Share prices of HBL before event & Share prices of HBL after event \\
\hline 1 & 212.4 & 209.00 \\
2 & 212.1 & 210.00 \\
3 & 213.0 & 211.00 \\
4 & 212.5 & 214.95 \\
5 & 207.5 & 214.01 \\
6 & 206.7 & 215.25 \\
7 & 207.9 & 216.88 \\
8 & 204.9 & 215.99 \\
9 & 199.2 & 215.25 \\
10 & 201.2 & 220.95 \\
\hline Total $\Delta$ & $-5.57 \%$ & $5.41 \%$ \\
\hline
\end{tabular}

Note: Percentage\% Increase or Decrease of Share Price

Figure 5 indicates that the trend of share prices of $\mathrm{HBL}$ before and after the event sponsoring announcement. This figure proposed a blue line showing share prices of HBL before-event and you can see it continuously goes down as well as the red line is presenting to the after-event share prices of HBL which shows consistently goes up after the announcement of event announcement. It means that the announcement of sports sponsorship has positively associated with the share prices of the sponsoring firms.

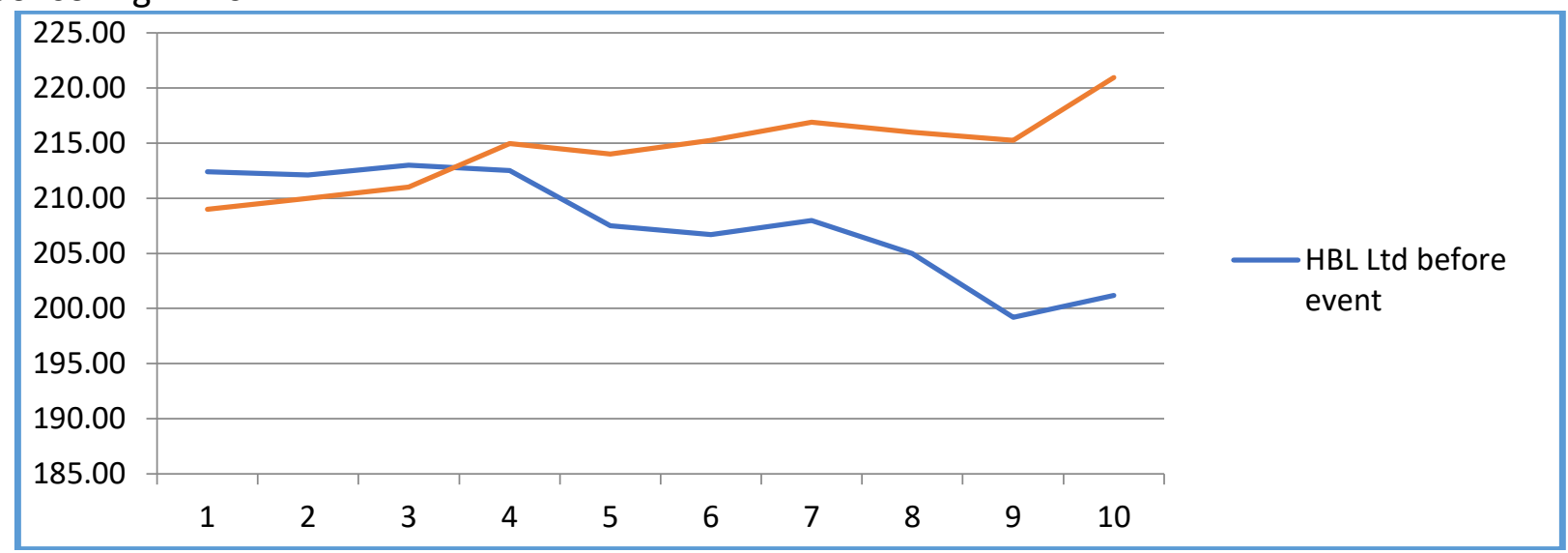

Figure 5.Share prices of HBL before and after event window; note; on vertical-axis is given share prices and horizontal-axis is given period.

\section{Forecasting Returns of HBL and KSE-100 Index}

\section{Before Event Analysis}

From table 6, a comprehensive and comparative view presented returns share prices of $\mathrm{HBL}$ and KSE-100 Index. The returns on the share prices of HBL isRs. 0.00661 before ten days of event announcement, occurring the event of sponsorship and during the before event-window the return was -0.00141 very next day and overall return was also -tive with Rs. -0.00476 daily basis on average. Similarly, at the same time-span, the return of KSE-100 Index was opened from Rs. -0.00120 and closes on Rs.0.02133before the event-window. But as total average return of KSE-100 Index 
INTERNATIONAL JOURNAL OF ACADEMIC RESEARCH IN BUSINESS AND SOCIAL SCIENCES Vol. 10, No. 6, June, 2020, E-ISSN: 2222-6990 @ 2020 HRMARS

before the event window was also -0.00469 . The trend of HBL and KSE-100 Index returns a negative trend before the event. However, the HBL's share price return is decreased by 0.00476 per day and the KSE-100 Index fell by 0.00469 per day. But with present circumstances is that the HBL returns are inefficient rather than KSE-100 Index.

Table 4.Comparison between HBL Ltd and KSE-100 Index returns before Event

\begin{tabular}{ccc}
\hline Sr. No & Share price return of HBL & KSE-100 Index return \\
\hline 1 & 0.00661 & -0.00120 \\
2 & -0.00141 & -0.00152 \\
3 & 0.00423 & -0.00367 \\
4 & -0.00235 & -0.00479 \\
5 & -0.02381 & -0.01113 \\
6 & -0.00386 & -0.00364 \\
7 & 0.00622 & -0.00361 \\
8 & -0.01453 & -0.02162 \\
9 & -0.02865 & -0.01707 \\
10 & 0.00999 & 0.02133 \\
\hline Total $\Delta$ & -0.00476 & -0.00469 \\
\hline
\end{tabular}

In figure 6, we can see the returns of HBL highly fluctuate and at the end of the before eventwindow, overall, not a satisfactory return is gained as we see on the average basis the yields are decreased with Re. 0.00476 per day. On the other hand, the returns of the KSE-100 Index are more stable than $\mathrm{HBL}$ and at the end a high rate of return obtained but overall decrease return with Rs. 0.00469 per-day. Therefore, it is concluded that the returns of the KSE-100 Index are more stable than HBL.

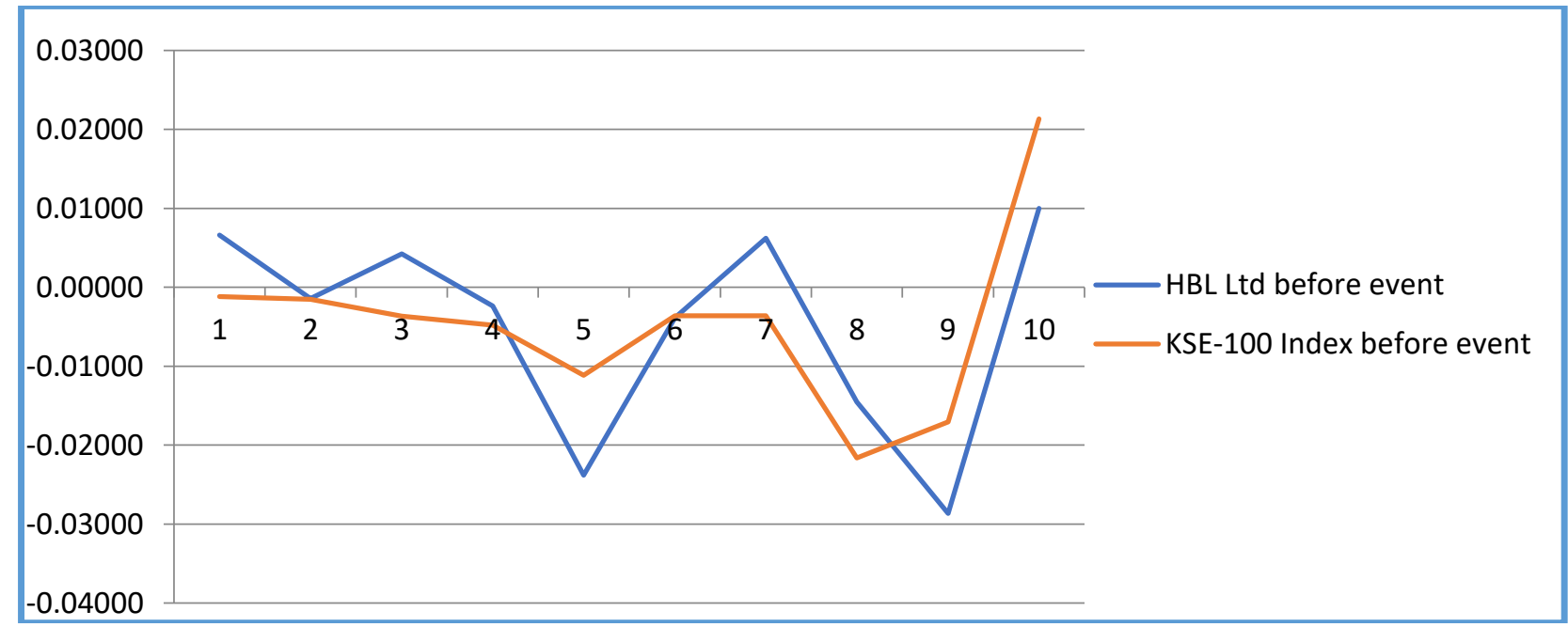

Figure 6. Returns of HBL and KSE-100 Index before the event, note; On vertical-axis is return values and horizontal-axis is time-span 
INTERNATIONAL JOURNAL OF ACADEMIC RESEARCH IN BUSINESS AND SOCIAL SCIENCES Vol. 10, No. 6, June, 2020, E-ISSN: 2222-6990 @ 2020 HRMARS

\section{After Event Window Forecasting}

Table 5 are summarized the daily \& average return of HBL and KSE-100 Index after the event window. As mention in the below table, the share return of HBL was Rs. -0.00239 but the very next day, the return came in a positive direction as Rs. 0.02614 . In addition, the average return of HBL was recorded Rs. 0.00532 after the event window. Furthermore, very next day from sponsorship announcement the KSE-100 Index return seemed in the positive zone with value 0.00437 and last day of after event window was also positive with value 0.01200 , but during the after event window four days " $3,6,7 \& 8$ were the negative side with following values $-0.00188,-0.00493,-0.00883 \&$ 0.00892 respectively. Moreover, the average return of the KSE-100 Index has 0,00166, which is less than the average value of $\mathrm{HBL}$ return comparatively. Consequently, the average share price of $\mathrm{HBL}$ was efficient rather than the average return of the KSE-100 Index after the sponsorship announcement.

Table 5: Comparison Returns of HBL with KSE-100 Index after Event

\begin{tabular}{ccc}
\hline Sr. No & Daily share prices return of HBL & Daily return of KSE-100 Index \\
\hline 1 & -0.00239 & 0.00437 \\
2 & 0.00477 & 0.00444 \\
3 & 0.00475 & -0.00188 \\
4 & 0.01855 & 0.00695 \\
5 & -0.00438 & 0.00579 \\
6 & 0.00578 & -0.00493 \\
7 & 0.00754 & -0.00883 \\
8 & -0.00411 & -0.00892 \\
9 & -0.00343 & 0.00760 \\
10 & 0.02614 & 0.01200 \\
\hline Total $\Delta$ & 0.00532 & 0.00166
\end{tabular}

In figure7, we can see that returns of HBL highly fluctuate and at the end of the after-event window, it provides a high progressive picture in comparison with returns of the KSE-100 Index. Overall a satisfactory-returns have gained as we see the average returns are increased Re. 0.00532 per-day. On the other hand, returns of the KSE-100 Index are not as satisfactory as HBL; thus, the gain value isRs.0.00166 per-day. Therefore, it is concluded that the returns of the share price of Habib Bank Limited are more suitable than the KSE-100 Index. 
INTERNATIONAL JOURNAL OF ACADEMIC RESEARCH IN BUSINESS AND SOCIAL SCIENCES

Vol. 10, No. 6, June, 2020, E-ISSN: 2222-6990 @ 2020 HRMARS

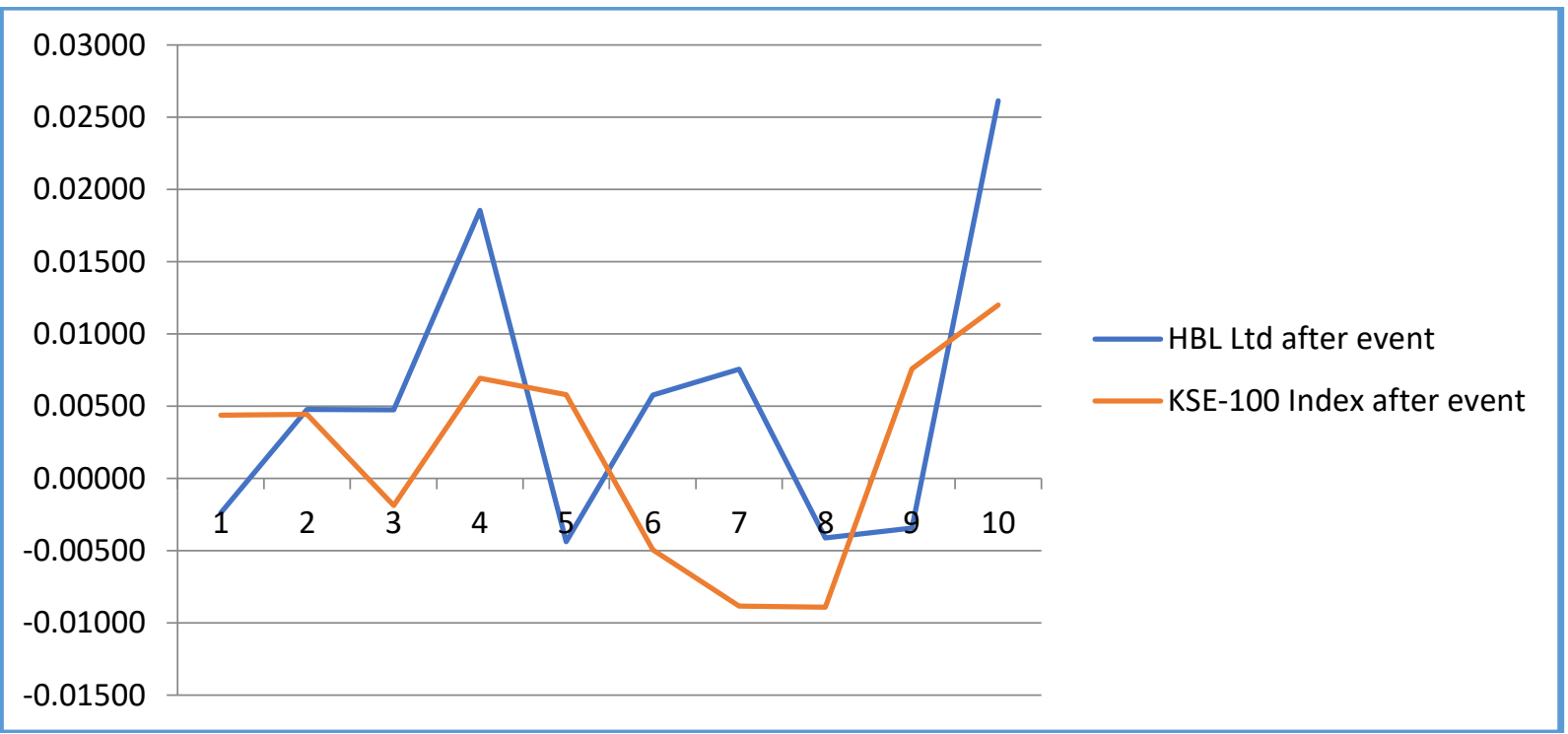

Figure 7. Returns of HBL and KSE-100 Index after the event, note: On vertical-axis is given share price daily return and horizontal-axis is given time-span.

\section{Forecasting of share Price of HBL before and after the event}

Finally, the comparison of returns of the share prices of Habib Bank Limited before and after the event and determine how and how much influence share prices of HBL by sponsoring events. Table 6 is justified that does or does not impact of sponsorship of PSL on the returns of the share price of the sponsoring organization HBL of Pakistan. Once we look before the event-window, the returns of the share price of HBL continually decreased which presents with -tive trends of returns and on average bases value 0.00476 per day dropped. Similarly, when the event appearance and the after the event-windows starts at that stage, the returns of the share price of $\mathrm{HBL}$ increased rapidly and positive returns starts which presenting that the event impacts the share price of the $H B L$ and returns of $\mathrm{HBL}$ ultimately will be increased. The trend returns of the share price of $\mathrm{HBL}$ after the event was +tive and an overall increase in returns was 0.00532 value per-day. Consequently, sponsorship of events does influence their share price performance of sponsoring firms. 
INTERNATIONAL JOURNAL OF ACADEMIC RESEARCH IN BUSINESS AND SOCIAL SCIENCES Vol. 10, No. 6, June, 2020, E-ISSN: 2222-6990 @ 2020 HRMARS

Table 6: Comparison between before and after returns of HBL

\begin{tabular}{ccc}
\hline Sr. No & $\begin{array}{c}\text { Daily share prices return of HBL } \\
\text { before event }\end{array}$ & $\begin{array}{c}\text { Daily share prices return of HBL } \\
\text { after sponsorship announcement }\end{array}$ \\
\hline 1 & 0.00661 & -0.00239 \\
2 & -0.00141 & 0.00477 \\
3 & 0.00423 & 0.00475 \\
4 & -0.00235 & 0.01855 \\
5 & -0.02381 & -0.00438 \\
6 & -0.00386 & 0.00578 \\
7 & 0.00622 & 0.00754 \\
8 & -0.01453 & -0.00411 \\
9 & -0.02865 & -0.00343 \\
10 & 0.00999 & 0.02614 \\
\hline Total $\Delta$ & -0.00476 & $\mathbf{0 . 0 0 5 3 2}$ \\
\hline
\end{tabular}

In figure 8 we can visualize the returns of HBL before the event highly deviate than after and even two times comes below the zero line with value 0.00476 per day. Besides, if once we consider after event returns of $\mathrm{HBL}$, so it leads to less fluctuation and more stable than before the event window. However, the trend of returns of the share price is positively and overall daily gain up 0.00532 perday. Hence, it shows that a positive impact of the announcement of sponsorship on sponsoring firms.

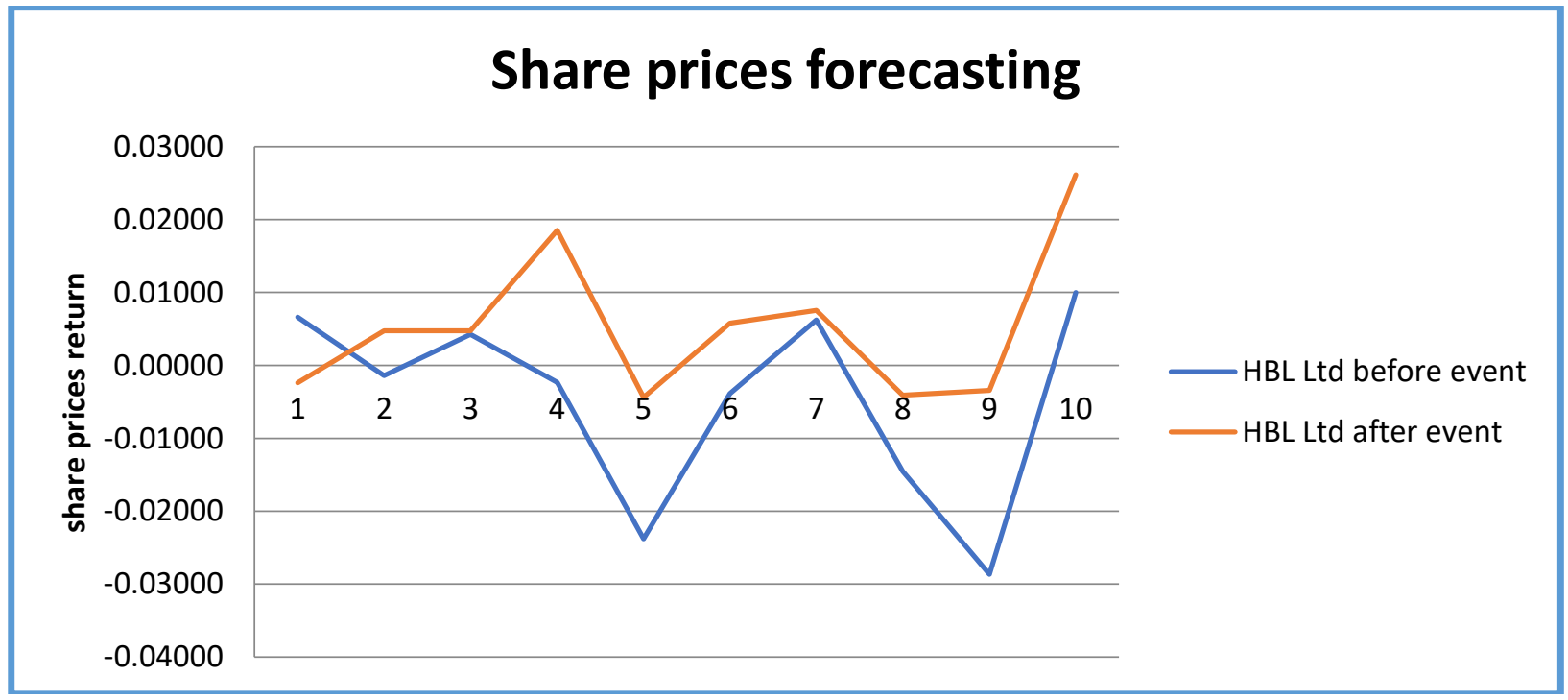

Figure 8. Returns of HBL before and after Event window

\section{Conclusion and Implementation}

After forecasting the event-based study, it concluded that before the event of sponsorship the trends of share price and the returns of share prices of Habib Bank Limited moving goes down. But event of announcement of sponsorship ensues the share price and returns of share price rapidly geos-up which shows that the announcement of sports sponsorship positively influences to the share price of the sponsoring firm. After forecast data set of pre \& post event of announcement of sports sponsorship it is proposed that announcement of sports sponsorship positively influenced to 
INTERNATIONAL JOURNAL OF ACADEMIC RESEARCH IN BUSINESS AND SOCIAL SCIENCES Vol. 10, No. 6, June, 2020, E-ISSN: 2222-6990 @ 2020 HRMARS

share price of sponsoring firms. Furthermore, academically this empirical research study will more helpful for students of finance in market perspective of financial behavior in future. Moreover, currant research study also leaves the appropriate knowledge for investors regarding way why is important financing in the field of Sports events.

Auther Contribution: We completely agree with the comments of the expert. : Present research study has summarized the dynamic phenomenon of companies share prices especially those companies which sponsoring sports. Moreover, this study has conducted on Pakistan Supper League (PSL) on Pakistan region. Consequently, we have concluded that share prices promotes by sponsoring sports. Because sports sponsorship has a big source of publicity and it constructive an optimistic image in between entire market. For this purpose, we have applied window base methodology (pre \& post event window from the day sponsorship announcement) and grab actual outcome. Thus, with the evidence of previous literature, this study has enrolled a new phenomenon in financial sector of Pakistan. Therefore, the entire research study has suggested that the organizations can be invested on sports side to promote our shares assets.

Funding Organization: The National Natural Sciences Foundation of China no. 71701082 and 71271103

\section{References}

Ferrand, A. M. (1999). Organization Image: the result of service value. Europan Journal of Marketing, 33, 387-402.

Arun, S. (2004). Game, set and client match. Media Asia, 9, 28-29.

Clark, J. M., Cornwell, T. B., \& Pruitt, S. W. (2002). Corporate stadium sponsorships, signalling theory, agency conflicts and shareholder wealth. Journal of Advertising Research, 42(6), 16-32.

Clark, J. M., Cornwell, T. B., \& Pruitt, S. W. (2009). The impact of title event sponsorship announcements on shareholder wealth. Marketing Letters, 20(2), 169-182.

Comwell, T. B., Pruitt, S. W., \& Van Ness, R. (2001). An Exploratory Analysis of the Value of Winning in Motorsports: Sponsorship linked Marketing and Shareholder Wealth. Journal of Advertising Research, 41, 17-31.

Cornwell, B., Pruitt, S. W., \& Clark, J. M. (2004). The official paper on official sponsorships: the impact of major league sports official sponsorship announcements on the stock prices of sponsoring firms: working paper.

Cornwell, T. B., Pruitt, S. W., \& Clark, J. M. (2005). The relationship between major-league sports' official sponsorship announcements and the stock prices of sponsoring firms. Journal of the Academy of Marketing Science, 33(4), 401-412.

Garland, R., Charbonneau, J., \& Macpherson, T. (2008). Measuring sport sponsorship effectiveness: links to existing behavior. Innovative Marketing, 4(1), 46-51.

Hassan, N. U., Imran, M. M., Amjad, M., \& Hussain, M. (2014). Effects of working capital management on firm performance: An empirical study of non-financial listed firms in Pakistan. International Journal of Academic Research in Business and Social Sciences, 4(6), 114-132.

Kim, J., \& Morris, J. D. (2003). The effect of advertising on the market value of firms: empirical evidence from the Super Bowl ads. Journal of Targeting, Measurement and Analysis for Marketing, 12(1), 53-65.

Kim, J. H., Shamsuddin, A., \& Lim, K.-P. (2011). Stock return predictability and the adaptive markets hypothesis: Evidence from century-long US data. Journal of Empirical Finance, 18(5), 868-879. 
INTERNATIONAL JOURNAL OF ACADEMIC RESEARCH IN BUSINESS AND SOCIAL SCIENCES

Vol. 10, No. 6, June, 2020, E-ISSN: 2222-6990 @ 2020 HRMARS

Meenaghan, J. A. (1993). Commercial sponsorship. European Journal of marketing, 17(7), 5-73.

Meenaghan, J. A., \& Flood, P. (1983). Commercial sponsorship: The misunderstood corporate art: Corporate Image.

Meenaghan, T., \& Shipley, D. (1999). Media effect in commercial sponsorship. European Journal of marketing.

Mishra, D. P., Bobinski Jr, G. S., \& Bhabra, H. S. (1997). Assessing the economic worth of corporate event sponsorships: A stock market perspective. Journal of Market-Focused Management, 2(2), 149-169.

Miyazaki, A. D., \& Morgan, A. G. (2001). Assessing the market value of sponsoring: corporate Olympic sponsorships. Journal of Advertising Research, 41(1), 9-15.

Pruitt, S. W., Cornwell, T. B., \& Clark, J. M. (2004). The NASCAR phenomenon: Auto racing sponsorships and shareholder wealth. Journal of Advertising Research, 44(3), 281-296.

Pynnonen, S. (2005). On regression based event study. Acta Wasaensia, 143(2), 327-354.

Ross, S., Westerfield, R., \& Jaffe, J. (2012). Corporate finance: McGraw-Hill Higher Education. 